\title{
PERBANDINGAN KINERJA KEUANGAN PERUSAHAAN BUMN SEKTOR PERTAMBANGAN DI INDONESIA DAN CHINA DILIHAT DARI RASIO KEUANGAN
}

\author{
COMPARISON OF FINANCIAL PERFORMANCE OF SOE MINING SECTOR \\ COMPANIES IN INDONESIA AND CHINA SEE FROM FINANCIAL RATIO
}

\author{
Yuli Nurul Afni Latuconsina, Nora Amelda Rizal \\ Universitas Telkom, Bandung, Indonesia \\ yulilatuconsina@student.telkomuniversity.ac.id ${ }^{1}$, norarizal@telkomuniversity.ac.id ${ }^{2}$
}

\begin{abstract}
ABSTRAK
Perkembangan ekonomi disetiap negara berbeda-beda begitu pula lingkungan bisnisnya. Perusahaan harus mengelola bisnisnya dengan baik agar terciptanya kinerja perusahaan yang baik. Kinerja perusahaan memiliki perbedaannya masing-masing, semakin baik perusahaan tersebut maka semakin menarik minat investor. Tujuan penelitian untuk mengetahui kinerja keuangan serta perbandingannya antara perusahaan BUMN sektor pertambangan di Indonesia dan china. Laporan keuangan perusahaan dari tahun 2014-2016 merupakan data sekunder yang digunakan. Objek penelitiannya yaitu perusahaan BUMN sektor pertambangan di Indonesia dan China. Kinerja keuangan dianalisis menggunakan tujuh rasio keuangan dan uji Wilcoxon Sign Rank Test. Hasil dari penelitian menunjukkan kinerja keuangan perusahaan di Indonesia dan China mengalami peningkatan dan penurunan yang disebabkan oleh faktor internal dan eksternal. Untuk meningkatkan bisnisnya perusahaan menggunakan strateginya masingmasing. Hasil penelitian juga menunjukkan antara perusahaan BUMN sektor pertambangan di Indonesia dan China tidak memiliki perbedaan kinerja keuangan pada rasio CR, DER, DAR, ITO, ROA dan ROE. Hanya terdapat perbedaan pada rasio TATO antara perusahaan BUMN sektor pertambangan di Indonesia dan China.
\end{abstract}

Kata kunci: kinerja keuangan, rasio keuangan, BUMN, Indonesia, China

\begin{abstract}
Economic development in each country is different as well as the business environment. Companies must manage their business well in order to create a good company performance. The performance of the company has its own distinction, the better the company the more attractive the investor. The purpose of research to know the financial performance as well as the comparison between SOEs mining sector companies in Indonesia and China. The company's financial reports from 2014-2016 is the secondary data used. The object of the research is the Indonesian state-owned mining company listed in IDX and China registered in SSE. Financial performance was analyzed using seven financial ratios and Wilcoxon Sign Rank Test. The results of the study show the financial performance of companies in Indonesia and China experienced an increase and decrease caused by internal and external factors. To improve its business, the company uses its own strategy. The results also show that between state-owned mining companies in Indonesia and China do not have differences in financial performance on the ratio of $C R, D E R, D A R, I T O, R O A$ and ROE. There is only a difference in the TATO ratio between SOE mining companies in Indonesia and China.
\end{abstract}

Keywords: financial performance, financial ratio, SOEs, Indonesia, China.

\section{PENDAHULUAN}

Pertumbuhan ekonomi yang bagus dan pengelolaan aset yang baik akan memberikan dampak bagi keuntungan negara, kinerja perusahaan dan kesejahteraan masyarakat.
Setiap negara memiliki perusahaan khusus milik negara (BUMN) yang bertujuan untuk meningkatkan aset yang dimiliki serta pertumbuhan ekonomi negara.

Indonesia memiliki jumlah aset BUMN 
sebesar Rp 6.694T dengan jumlah 118 BUMN yang terbagi menjadi 13 sektor perindustrian. Pada tahun 2016 BUMN memberikan kontribusi kepada negara dalam bentuk deviden dan pajak belum termasuk penerima negara bukan pajak (PNPB) sebesar Rp 202 triliun. Sedangkan belanja modal yang dilakukan oleh BUMN tahun 2016 sebesar Rp 298 triliun. Belanja modal mengalami pertumbuhan 35\% dibandingkan tahun 2015 dan yang menjadi fokus belanja modal adalah infrastruktur, energi, dan konektivitas(Akhir, 2017). Meningkatnya kinerja BUMN memberikan dampak yang baik untuk negara. Berdasarkan catatan dari Badan Koordinasi Penanaman Modal (BKPM), industri yang paling menarik minat investor adalah industri pertambangan(Kusuma, 2017). Pertumbuhan sektor pertambangan bisa dilihat dari pergerakan harga komoditasnya. Harga batubara berdasarkan Harga Batubara Acuan (HBA) pada tahun 2014 sebesar US\$64,65 per ton dan pada akhir desember 2015 sebesar US\$53,51 per ton(Aron, 2016). Awal tahun 2016 harga batubara hanya berkisar US\$60 per ton, kemudian meningkat menjadi US $\$ 80$ per ton(Rachman, 2017).

China memiliki 102 BUMN yang dikelola oleh pemerintah. Pada empat bulan pertama pada tahun 2017, China mendapatkan keuntungan yang diperoleh dari BUMN sebesar 835 milliar yuan(ChinaDaily, 2017). China memiliki nilai Current Account Balance pada tahun 2015 sebesar \$304.2 billion dan pada tahun 2016 sebesar \$196.4 billion. China menjadi Negara dengan surplus terbesar pada tahun 2016 yaitu sebesar $\$ 510.730$ billion("China Current Account Balance,” 2017).
Perusahaan Shenhua Group Corp yang merupakan perusahaan pertambangan batubara terbesar di negara china akan melakukan merger dengan China Guodian Corp untuk mengelola aset gabungan sebesar \$271 milliar (Puspasari, 2017).

Persaingan yang semakin ketat membuat suatu negara harus cermat dalam mengelola perusahaan serta keuangannya. Kinerja perusahaan yang baik akan lebih menarik minat investor. Kinerja keuangan perusahaan bisa dilihat pada laporan keuangannya dan dianalisis menggunakan alat analisis keuangan yaitu rasio keuangan.

Rasio profitabilitas menunjukkan kemampuan menghasilkan laba dari hasil operasi perusahaan. Penelitan oleh Haque (2014) menganalisis perbandingna kinerja kelompok perbankkan di India menggunakan rasio profitabilitas dengan menggunakan metode analisis varians (ANOVA). Kemampuan perusahaan untuk memenuhi kewajiban jangka pendeknya ditunjukkan oleh rasio likuiditas. Rasio profitabilitas dan likuiditas tersebut digunakan oleh Islam (2014)dalam penilaian kinerja National Bank Limited di Bangladesh menggunakan rasio profitabilitas, likuiditas dan kinerja kredit dengan menggunakan metode paired $T$ test. Rasio Solvabilitas/manajemen utang untuk mengetahui seberapa besar perusahaan dibiayai oleh utang. Hal ini sejalan dengan penelitian oleh Jothi \& Kalaivani (2015) meneliti tentang perbandingan kinerja perusahaan Honda dan Toyota menggunakan rasio profitabilitas, likuiditas dan solvabilitas dengan menggunakan metode alat statistik.

Rasio Manajemen Aset untuk mengetahui kemampuan perusahaan dalam mengelola 
asetnya. Penelitian oleh Rhamadana (2016)dalam penilaian kinerja keuangan PT. H.M Sampoerna Tbk menggunakan rasio profitabilitas, likuiditas, solvabilitas dan rasio aktivitas dengan teknik analisis datatime series.Selanjutnya penelitian oleh Agustin, Darminto, \& Handayani (2013) meneliti tentang penilaian kinerja keuangan perusahaan semen menggunakan rasio profitabilitas, rasio utang, likuiditas, aktivitas, rasio pasar dan metode time series. Penelitian selanjutnya oleh Hunjra \& Bashir (2014) meneliti tentang perbandingan kinerja keuangan antara 5 bank konvensional dan 5 bank syariah di Pakistan menggunakan rasio profitabilitas, likuiditas, risiko dan solvabilitas, rasio kecukupan modal, rasio operasional, rasio arus kas dan rasio deployment menggunakan metode Independent T-test.

Kinerja perusahaan disuatu Negara memiliki perbedaannya masing-masing. Untuk mengetahui perbedaan kinerja perusahaan tersebut dapat dilihat dari perbandingan analisa rasio keuangannya. Dengan membandingkan kinerja perusahaan antara Negara dapat memberikan informasi mengenai kelemahan maupun kelebihan satu sama lain, pengambilan keputusan dan dapat dijadikan evaluasi oleh Negara yang bersangkutan. Hal ini sejalan dengan penelitian Asheghian (2012)yang meneliti perbandingan kinerja keuangan antara perusahaan Amerika $d$ an China menggunakan rasio manajemen utang, manajemen aset danprofitabilitas dengan menggunakan analisis rasio keuangan dan uji Wilcoxon Sign Rank Test Test. Penelitian lain oleh Liu, O'Farrell, Wei, \& Yao (2013) meneliti tentang perbandingan kinerja keuangan antara perusahaan manufaktur China dan Jepang menggunakan rasio likuiditas, solvabilitas, aktivitas, dan profitabilitas dengan menggunakan analisis rasio keuangan dan uji Wilcoxon Sign Rank Test Test.

Berdasarkan latar belakang dan penelitianpenelitian sebelumnya, peneliti ingin mengetahui perbandingan kinerja keuangan perusahaan BUMN sektor pertambangan di Indonesia dan China menggunakan analisis rasio Likuiditas (Current Ratio (CR)), Manajemen utang (Debt to Equity Ratio (DER), Debt to Asset Ratio (DAR)), Manajemen aset (Inventory Turnover (ITO), Total Asset Turnover (TATO)), Profitabilitas (Return on Assets (ROA), Return on Equity (ROE)).Penelitian ini memiliki hipotesis sebagai berikut:

H0: Tidak terdapat perbedaan kinerja keuangan antara perusahaan BUMN sektor pertambangan di Indonesia dan China

H1: Terdapat perbedaan kinerja keuangan antara perusahaan BUMN sektor pertambangan di Indonesia dan China

\section{METODOLOGI PENELITIAN}

Jenis penelitian kuantitatif dengan menggunakan metode deskriptif. Metode deskriptif digunakan untuk menganalisis kinerja keuangan serta perbandingannya antara perusahaan BUMN sektor pertambangan di Indonesian dan China. Populasi dalam penelitian ini adalah perusahaan BUMN sektor pertambangan di Indonesia dan China. Teknik pengambilan sampel yaitu purposive sampling. Dimana 
sampel yang terpilih atas dasar kriteria yang ditetapkan oleh peneliti. Kriteria-kriteria itu adalah:

1. Perusahaan BUMN sektor pertambangan Indonesia yang masuk Bursa Efek Indonesia (BEI).

2. Perusahaan BUMN sektor pertambangan China yang masuk Bursa Efek Shanghai (SSE).

3. Ketersediaan laporan keuangan perusahaan periode 2014-2016 yang dapat diakses peneliti.

4. Ketersediaan laporan keuangan perusahaan BUMN China periode 2014-2016 yang menggunakan bahasa internasional.

Perusahaan yang terpilih yaitu PT. Aneka Tambang Tbk, PT. Timah Tbk, PT. Bukit Asam Tbk, China Shenhua Energy Co, Ltd, Metallurgical Corporation of China Ltd dan China Molybdenum Co, Ltd. Dalam penelitian ini menggunakan analisis rasio keuangan menggunakan tujuh rasio yaitu CR, DAR, DER, ITO, TATO, ROA, ROE danUji Wilcoxon Sign Rank Test. Menurut Liu, O’Farrell, Wei, \& Yao (2013) Uji Wilcoxon Sign Rank Test adalah uji nonparametik yang datanya tidak berdistribusi normal dan ukuran sampel yang kecil. Uji Wilcoxon Sign
Rank Test digunakan untuk menguji apakah ada perbedaan atau tidak dari dua data yang berpasangan. Jika nilai signifikan yang diperoleh $>0.05$ maka hipotesis $\mathrm{H} 0$ diterima.

\section{HASIL DAN PEMBAHASAN}

Menurut Utari, Purwanti, \& Prawironegoro (2014) Kinerja keuangan adalah hasil kegiatan perusahaan yang disajikan dalam bentuk angka-angka kauangan. Kinerja keuangan terlihat pada laporan keuangan yang dimiliki perusahaan. Menurut Brigham \& Houston (2009) Informasi tentang hasil usaha dan posisi perusahaan di waktu tertentu disebut laporan keuangan. Laporan keuangan dapat digunakan investor sebagai informasi dalam pengambilan keputusan untuk berinvestasi. Untuk menganalisis kondisi keuangan atau membandingkan kinerja keuangan suatu perusahaan dapat menggunakan rasio keuangan. Menurut Horne et al (dalam Kasmir, 2012)Rasio keuangan yaitu indeks yang menghubungkan dua buah data keuangan dan membagi satu angka dengan angka yang lain. Berikut adalah tabel yang membandingkan rasio keuangan dari perusahaan yang di teliti.

Tabel 1

Rasio keuangan

\begin{tabular}{|c|c|c|c|c|c|c|c|c|c|}
\hline \multirow{3}{*}{ No } & \multirow{3}{*}{ Perusahaan } & \multirow{3}{*}{ Tahun } & \multicolumn{7}{|c|}{ Rasio Keuangan } \\
\hline & & & \multirow{2}{*}{$\frac{\text { Likuiditas }}{\mathrm{CR}}$} & \multicolumn{2}{|c|}{ Manajemen Utang } & \multicolumn{2}{|c|}{ Manajemen Aset } & \multicolumn{2}{|c|}{ Profitabilitas } \\
\hline & & & & DAR & DER & ITO & TATO & ROA & ROE \\
\hline \multirow{4}{*}{1} & \multirow{4}{*}{$\begin{array}{l}\text { PT. Aneka } \\
\text { Tambang Tbk }\end{array}$} & 2014 & 1.64 & 0.45 & 0.83 & 5.35 & 0.43 & -0.03 & -0.06 \\
\hline & & 2015 & 2.59 & 0.40 & 0.66 & 6.01 & 0.35 & -0.05 & -0.08 \\
\hline & & 2016 & 2.44 & 0.39 & 0.63 & 6.56 & 0.30 & 0.00 & 0.00 \\
\hline & & Rata-rata & 2.23 & 0.41 & 0.70 & 5.97 & 0.36 & -0.03 & -0.05 \\
\hline \multirow{4}{*}{2} & \multirow{4}{*}{ PT. Timah Tbk } & 2014 & 1.85 & 0.54 & 1.19 & 2.22 & 0.76 & 0.07 & 0.15 \\
\hline & & 2015 & 1.82 & 0.42 & 0.73 & 2.22 & 0.74 & 0.01 & 0.02 \\
\hline & & 2016 & 1.71 & 0.41 & 0.69 & 2.43 & 0.73 & 0.03 & 0.04 \\
\hline & & Rata-rata & 1.79 & 0.46 & 0.87 & 2.29 & 0.74 & 0.04 & 0.07 \\
\hline
\end{tabular}




\begin{tabular}{|c|c|c|c|c|c|c|c|c|c|}
\hline \multirow{4}{*}{3} & \multirow{4}{*}{$\begin{array}{l}\text { PT. Bukit Asam } \\
\text { Tbk }\end{array}$} & 2014 & 2.07 & 0.43 & 0.74 & 12.66 & 0.88 & 0.13 & 0.22 \\
\hline & & 2015 & 1.54 & 0.45 & 0.82 & 11.23 & 0.82 & 0.12 & 0.22 \\
\hline & & 2016 & 1.66 & 0.43 & 0.76 & 12.75 & 0.76 & 0.11 & 0.19 \\
\hline & & Rata-rata & 1.76 & 0.44 & 0.77 & 12.21 & 0.82 & 0.12 & 0.21 \\
\hline \multirow{4}{*}{4} & \multirow{4}{*}{$\begin{array}{l}\text { China Shenhua } \\
\text { Energy Co, Ltd }\end{array}$} & 2014 & 1.08 & 0.34 & 0.51 & 15.84 & 0.46 & 0.09 & 0.13 \\
\hline & & 2015 & 1.193 & 0.35 & 0.54 & 13.82 & 0.32 & 0.04 & 0.07 \\
\hline & & 2016 & 1.190 & 0.33 & 0.50 & 13.73 & 0.32 & 0.06 & 0.08 \\
\hline & & Rata-rata & 1.15 & 0.34 & 0.51 & 14.46 & 0.36 & 0.06 & 0.10 \\
\hline \multirow{4}{*}{5} & \multirow{4}{*}{$\begin{array}{l}\text { Metallurgical } \\
\text { Corporation of } \\
\text { China Ltd }\end{array}$} & 2014 & 1.14 & 0.82 & 4.62 & 2.03 & 0.66 & 0.01 & 0.074 \\
\hline & & 2015 & 1.17 & 0.79 & 3.83 & 1.88 & 0.63 & 0.01 & 0.070 \\
\hline & & 2016 & 1.18 & 0.78 & 3.54 & 1.80 & 0.58 & 0.02 & 0.071 \\
\hline & & Rata-rata & 1.16 & 0.80 & 4.00 & 1.90 & 0.63 & 0.01 & 0.07 \\
\hline \multirow{4}{*}{6} & \multirow{4}{*}{$\begin{array}{l}\text { China } \\
\text { Molybdenum Co, } \\
\text { Ltd }\end{array}$} & 2014 & 4.92 & 0.46 & 0.85 & 9.00 & 0.24 & 0.06 & 0.12 \\
\hline & & 2015 & 1.79 & 0.42 & 0.73 & 4.84 & 0.14 & 0.02 & 0.04 \\
\hline & & 2016 & 1.24 & 0.61 & 1.57 & 0.74 & 0.08 & 0.01 & 0.03 \\
\hline & & Rata-rata & 2.65 & 0.50 & 1.05 & 4.86 & 0.15 & 0.03 & 0.06 \\
\hline
\end{tabular}

Sumber: Data diolah

\section{Analisis rasio keuangan}

Analisis rasio keuangan pada tabel 1 digunakan untuk melihat kinerja keuangan perusahaan. Pembahasan analisis rasio keuangan dijelaskan berdasarkan aspek keuangan dan aspek manajemen dari masingmasing perusahaan di kedua Negara tersebut.

a. Aspek keuangan

1) Likuiditas

Menurut Brigham \& Houston (2009), likuiditas adalah hubungan antara kewajiban jangka pendek dengan aset lancar. Salah satu alat ukur dari rasio ini adalah rasio lancar (current ratio), yang merupakan mampunya perusahaaan memenuhi kewajiban jangka pendek menggunakan aset lancar dapat dilihat pada rasio lancar. Rumus menghitung CR:

$$
C R=\frac{\text { aset lancar }}{\text { kewajiban lancar }}
$$

Pada perusahaan Indonesia, berdasarkan hasil diatas menunjukkan bahwa perusahaan PT. Aneka Tambang Tbk mengalami peningkatan rasio $\mathrm{CR}$ pada tahun 2015 kemudian menurun di tahun 2016. Perusahaan PT. Timah Tbk mengalami penurunan rasio CR dari tahun 2014-2016. Sedangkan perusahaan PT. Bukit Asam Tbk mengalami penurunan rasio $\mathrm{CR}$ pada tahun 2015 kemudian meningkat pada tahun 2016.

Sedangkan untuk perusahaan China, berdasarkan hasil diatas menunjukkan bahwa rasio CR untuk perusahaan China Shenhua Energy Co, Ltd pada tahun 2015 mengalami peningkatan kemudian menurun di tahun 2016. Perusahaan Metallurgical Corporation of China Ltd mengalami peningkatan rasio CR dari tahun 2014-2016. Sedangkan perusahaan China Molybdenum Co, Ltd mengalami penurunan rasio $\mathrm{CR}$ dari tahun 2014-2016.

2) Manajemen utang

Menurut Brigham \& Houston (2009), manajemen utang menunjukkan pendanaan perusahaan menggunakan utang. Salah satu alat ukur yang dipakai dalam penelitian ini adalah rasio utang terhadap aset (debt to asset ratio), yang menunjukkan besarnya utang yang digunakan untuk pengelolaan asset dan rasio utang terhadap ekuitas (debt to equity ratio), yang menunjukkan jumlah modal yang berasal dari utang. Rumus untuk menghitung DAR dan 
DER adalah sebagai berikut:

$$
D E R=\frac{\text { total utang }}{\text { total ekuitas }}
$$

Pada perusahaan Indonesia, berdasarkan hasil yang didapat menunjukkan bahwa rasio DAR dan DER tahun 2014-2016 perusahaan PT. Aneka Tambang Tbk dan PT. Timah Tbk mengalami penurunan. Sedangkan untuk perusahaan PT. Bukit Asam Tbk mengalami peningkatan pada tahun 2015 kemudian menurun pada tahun 2016 .

Hasil pada perusahaan China, menunjukkan bahwa rasio DAR dan DER perusahaan China Shenhua Energy Co, Ltd mengalami peningkatan pada tahun 2015 kemudian ditahun 2016 mengalami penurunan. Rasio DAR dan DER pada perusahaan Metallurgical Corporation of China Ltd mengalami penurunan dari tahun 2014-2016. Sedangkan perusahaan China Molybdenum Co, Ltd mengalami penurunan pada tahun 2015 kemudian peningkatan pada tahun 2016.

3) Manajemen aset

Menurut Brigham \& Houston (2009) Manajemen aset menunjukkan keefektifan perusahaan dalam mengelola asetnya. Salah satu alat ukur yang dipakai dalam penelitian ini adalah perputaran persediaan (inventory turnover), yang menggambarkan seberapa cepat persediaan barang dagang berhasil dijual kepada pelanggan dan perputaran total aset (total assets turnover), yang menggambarkan keefektifan perusahaan dalam pengelolaan total aset yang dimiliki. Rumus untuk menghitung ITO dan TATO adalah sebagai berikut
Pada perusahaan Indonesia, berdasarkan hasil yang didapat menunjukkan bahwa dari tahun 2014-2016 rasio ITO untuk perusahaan PT. Aneka Tambang Tbk dan PT. Timah Tbk mengalami peningkatan. Sedangkan perusahaan PT. Bukit Asam Tbk mengalami penurunan pada tahun 2015 kemudian meningkat di tahun 2016. Untuk rasio TATO menunjukkan bahwa dari tahun 2014-2016 seluruh perusahaan Indonesia mengalami penurunan. Sedangkan pada seluruh perusahaan China, hasil yang didapat menunjukkan bahwa dari tahun 2014-2016 rasio ITO dan TATO mengalami penurunan.

4) Profitabilitas

Menurut Brigham \& Houston (2009) Kemampuan yang ditunjukkan perusahaan untuk menghasilkan laba dari hasil operasi perusahaan ditunjukkan oleh rasio profitabilitas. Salah satu alat ukur yang dipakai dalam penelitian ini adalah hasil pengembalian atas aset (return on assets), yang menunjukkan laba yang diperoleh dari pengelolaan total asset dan hasil pengembalian atas ekuitas (return on equity), yang menunjukkan laba yang diperoleh dari investasi yang dimiliki. Rumus untuk menghitung ROA dan ROE, adalah sebagai berikut:

$R O A=\frac{\text { laba bersih }}{\text { total aset }} \quad R O E=\frac{\text { laba bersih }}{\text { total ekuitas }}$

Pada perusahaan Indonesia, hasil yang didapat menunjukkan bahwa pada tahun 2015 perusahaan PT. Aneka Tambang Tbk dan PT. Timah Tbk mengalami penurunan ROA dan ROE kemudian meningkat di tahun 2016. Hasil ROA dan ROE untuk perusahaan PT. Bukit Asam Tbk mengalami penurunan dari tahun 2014-2016. 
Sedangkan pada perusahaan China, berdasarkan hasil yang didapat menunjukkan perusahaan China Shenhua Energy Co, Ltd dan Metallurgical Corporation of China Ltd mengalami penurunan rasio ROA dan ROE pada tahun 2015 kemudian mengalami peningkatan pada tahun 2016. Sedangkan perusahaan China Molybdenum Co, Ltd mengalami penurunan rasio ROA dan ROE dari tahun 2014-2016.

\section{b. Aspek manajemen}

Faktor internal dan faktor eksternal yang menyebabkan kinerja keuangan perusahaan yang ditunjukkan oleh rasio keuangan mengalami peningkatan dan penurunan. Untuk perusahaan Indonesia, penurunan kinerja yang disebabkan oleh kendala internal yang dialami perusahaan yaitu penurunan aset, meningkatnya utang yang dimiliki, kenaikan beban usaha, penurunan penjualan, dan penurunan laba. Untuk perusahaan China, penurunan kinerja yang disebabkan oleh kendala internal yang dialami perusahaan yaitu penurunan aset, meningkatnya utang yang dimiliki, kenaikan beban usaha, penurunan penjualan, penurunan laba, dan menurunya permintaan industri. Perusahaan BUMN dikedua Negara mengalami kendala ekternal yang sama yaitu pertumbuhan ekonomi, nilai tukar mata uang dan penurunan harga komoditas. Peningkatan kinerja yang dialami seluruh perusahan disebabkan oleh meningkatnya aset yang dimiliki perusahaan, beban usaha yang menurun, penjualan yang meningkat dan harga komoditas yang stabil.

Dalam meningkatkan kinerja keuangan, perusahaan memiliki strateginya masingmasingnya. Untuk perusahaan Indonesia, perusahaan mengawasi dan memonitor kas, efesiensi operasional seperti menekan biaya, menerbitkan saham atau menjual aset untuk meminimalkan utang dan menambah modal, merekrut SDM yang berkualitas, ekspansi pasar, meningkatkan teknologi dan lain-lain. Begitupula dengan perusahaan China, perusahaan melakukan kontrol dan mengendalikan laporan keuangan, melindungi aset menggunakan instrumen derivatif, ekspansi pasar, meningkatkan teknologi, merekrut SDM yang berkualitas dan lain-lain.

\section{Perbandingan kinerja keuangan antara perusahaan BUMN dikedua} Negara

Tabel 2

Hasil uji wilcoxon sign rank test

\begin{tabular}{lcc}
\hline \multicolumn{1}{c}{ Kategori } & Rasio & $\begin{array}{c}\text { Asymp. Sig. } \\
\text { (2-tailed) }\end{array}$ \\
\hline Likuiditas & CR & 0.139 \\
Manajemen Utang & DAR & 0.260 \\
& DER & 0.260 \\
Manajemen Aset & ITO & 0.859 \\
& TATO & 0.024 \\
Profitabilitas & ROA & 0.678 \\
& ROE & 0.953 \\
\hline
\end{tabular}

Sumber: Data diolah

Dari tabel 2, berdasarkan hasil perhitungan uji Wilcoxon Sign Rank Test, diperoleh hasil sebagai berikut:

a. Likuiditas

Nilai signifikan rasio CR sebesar 0.139 $>0.05$ maka H0 diterima. Dengan diterimanya H0 menunjukkan tidak terdapat perbedaan kinerja keuangan antara perusahaan Indonesia dan China. Perusahaan di kedua Negara tersebut memiliki kesamaan dalam hal memenuhi kewajiban jangka pendeknya menggunakan aset lancar yang dimiliki.

b. Manajemen utang 
Nilai signifikan rasio DAR $0.260>0.05$, maka H0 diterima. Dengan diterimanya H0 menunjukkan tidak terdapat perbedaan kinerja keuangan antara perusahaan Indonesia dan China. Perusahaan dikedua Negara tersebut memiliki kesamaan dalam hal pembiayaan aset perusahaan menggunakan utang.

Nilai signifikan rasio DER $0.260>0.05$, maka H0 diterima. Dengan diterimanya H0 menunjukkan tidak terdapat perbedaan kinerja keuangan antara perusahaan Indonesia dan China. Perusahaan di kedua Negara tersebut memiliki kesamaan dalam hal pembiayaan aset perusahaan menggunakan utang dari total modal yang dimiliki perusahaan.

\section{c. Manajemen aset}

Nilai signifikan rasio ITO sebesar $0.859>$ 0.05 maka H0 diterima. Dengan diterimanya H0 menunjukkan tidak terdapat perbedaan kinerja keuangan antara perusahaan Indonesia dan China Perusahaan di kedua Negara tersebut memiliki kesamaan dalam hal perputaran persediaan barang dagang.

Nilai signifikan rasio TATO 0.024. $<0.05$ maka H0 ditolak, yaitu terdapat perbedaan kinerja keuangan antara perusahaan Indonesia dan China. Perusahaan di kedua Negara tersebut memiliki perbedaan dalam hal perputaran total aset yang dimiliki.

\section{d. Profitabilitas}

Nilai signifikan rasio ROA dan ROE lebih besar dari 0.05 yaitu sebesar 0.678 dan 0.953 maka H0 diterima. Dengan diterimanya H0 menunjukkan tidak terdapat perbedaan kinerja keuangan antara perusahaan Indonesia dan China. Perusahaan di kedua Negara tersebut memiliki kesamaan dalam hal tingkat pengembalian aset dan tingkat pengembalian ekuitas.

\section{SIMPULAN}

Penelitian ini meneliti tentang perbandingan kinerja keuangan perusahaan BUMN sektor pertambangan di Indonesia dan China dilihat dari rasio keuangan. Perusahaan tersebut yaitu PT. Aneka Tambang Tbk, PT. Timah Tbk, PT. Bukit Asam Tbk, China Shenhua Energy Co, Ltd, Metallurgical Corporation of China Ltd dan China Molybdenum Co, Ltd. Data sekunder yang digunakan yaitu laporan keuangan dari tahun 2014-2016. Menganalisis kinerja keuangan menggunakan tujuh rasio yaitu CR, DAR, DER, ITO, TATO, ROA, ROE dan uji Wilcoxon Sign Rank Test.

Dari hasil analisis rasio keuangan menunjukkan kinerja keuangan untuk seluruh perusahaan mengalami peningkatan dan penurunan pada tahun 2014-2016. Peningkatan dan penurunan kinerja keuangan disebabkan faktor internal dan eksternal yang dialami perusahaan. Hasil juga menunjukkan tidak terdapat perbedaaan kinerja keuangan antara perusahaan BUMN sektor pertambangan di Indonesia dan China dilihat dari hasil rasio CR, DAR, DER, ITO, ROA dan ROE. Hanya pada rasio TATO menunjukkan terdapat perbedaan kinerja keuangan antara perusahaan BUMN sektor pertambangan di Indonesia dan China.

Implikasi dari penelitian ini, dimana penelitian ini dapat dijadikan bahan referensi serta lebih dikembangkan lagi penelitiannya, baik itu dalam sektor perindustrian, Negara dan metode yang digunakan. Untuk Perusahaan, diharapkan hasil penelitian dapat dijadikan acuan untuk mengevaluasi kinerja serta meningkatkan bisnis yang dimiliki perusahaan di masing-masing negara. Pengelolaan aset serta manajemen utang lebih 
diperhatikan agar laba yang diharapkan dapat terwujud. Perusahaan bisa mencontoh dan menerapkan strategi dari perusahaan yang lebih baik pengelolaan bisnisnya. Sedangkan bagi investor, penelitian ini dapat digunakan sebagai informasi pengambilan keputusan untuk berinvestasi. Dengan hasil penelitian ini investor dapat memilih perusahaan mana yang lebih baik dijadikan tempat berinvestasi.

\section{DAFTAR RUJUKAN}

Agustin, A. L. A., Darminto., \& Handayani, S. R. (2013). Analisis Rasio Keuangan untuk Menilai Kinerja Keuangan Perusahaan. Jurnal Administrasi Bisnis, 2(1), 12-20. Retrieved from https://media.neliti.com/media/publications/72532-ID-analisis-rasiokeuangan-untuk-menilai-ki.pdf

Akhir, D. J. (2017). Vitalnya Peran BUMN dalam Pembayaran PNBP, Kontribusi Paling Tinggi!: Okezone Economy. Retrieved March 24, 2018, from https://economy. okezone.com/read/2017/11/30/20/1823351/vitalnya-peran-bumn-dalam-pembayaranpnbp-kontribusi-paling-tinggi

Aron, H. H. B. (2016). Harga Batu Bara Acuan Desember 2015 Turun Jadi US\$ 53,51/Ton. Retrieved March 24, 2018, from https://finance.detik.com/energi/3117739/harga-batubara-acuan-desember-2015-turun-jadi-us-5351ton

Asheghian, P. (2012). The Comparative Financial Managerial Performance of U.S. Firms and Chinese Firms. Journal of Finance and Investment Analysis, 1(2), 119-135. Retrieved from http://www.scienpress.com/Upload/JFIA\%2FVol 1_2_5.pdf

Brigham, E. F., \& Houston, J. F. (2009). Dasar-Dasar Manajemen Keuangan. Jakarta: Salemba Empat.

China Current Account Balance. (2017). Retrieved March 24, 2018, from https://www.cia.gov/ library/publications/the-worldfactbook/geos/ch.html

ChinaDaily. (2017). China State-owned enterprises to be divided into three categories. Retrieved March 24, 2018, from http://www.chinadaily.com.cn/business/2017-06/05/ content 29620256.htm

Hunjra, A. I., \& Bashir, A. (2014). Comparative Financial Performance Analysis of Conventional and Islamic Banks in Pakistan. Bulletin of Business and Economics, 3(4), 196-206. Retrieved from http://rfh.org.pk/jur/paper/comparative-financial-performanceanalysis-of-conventional-and-islamic-banks-in-pakistan

Islam, M. A. (2014). An Analysis of the Financial Performance of National Bank Limited Using Financial Ratio. SSRN Electronic Journal, 2(5), 121-129. https://doi.org/10.2139/ ssrn. 2512776

Jothi, K., \& Kalaivani, P. (2015). A Study on Financial Performance of Honda and Toyota Automobile Company A Comparative Analysis. Journal of Progressive Research in Social Sciences, 2(1), 33-35. Retrieved from http://scitecresearch.com/journals/index. $\mathrm{php} / \mathrm{jprss} /$ article/view/155

Kasmir. (2012). Analisis Laporan Keuangan. Jakarta: Rajawali Pers.

Kusuma, H. (2017). Ritel Lesu, Sektor Tambang Justru Lagi Tancap Gas. Retrieved March 24, 2018, from https://finance.detik.com/berita-ekonomi-bisnis/d-3586023/ritel-lesusektor-tambang-justru-lagi-tancap-gas. 
Liu, C., O’Farrell, G., Wei, K., \& Yao, L. J. (2013). Ratio analysis comparability between Chinese and Japanese firms. Journal of Asia Business Studies, 7(2), 185-199. https:// doi.org/10.1108/15587891311319468

Puspasari, I. G. (2017). China is Creating the World's Largest Power Company. Retrieved March 24, 2018, from https://seasia.co/2017/09/06/china-is-creating-the-world-slargest-power-company

Rachman, F. F. (2017). Sektor Pertambangan Pilihan Utama China Investasi di RI. Retrieved March 24, 2018, from https://finance.detik.com/energi/d-3399341/sektorpertambangan-pilihan-utama-china-investasi-di-ri

Rhamadana, R. B. (2016). Analisis Rasio Keuangan untuk Menilain Kinerja Keuangan pada PT. H.M Sampoerna Tbk. Jurnal Ilmu dan Riset Manajemen, 5(7), 1-18. Retrieved from https://ejournal.stiesia.ac.id/jirm/article/viewFile/1595/1559

Utari, D., Purwanti, A., \& Prawironegoro, A. (2014). Manajemen Keuangan : kajian praktek dan teori dalam mengelola keuangan organisasi perusahaan. Jakarta: Mitrawacanamedia. 